\title{
Ungaretti em São Paulo
}

ANTONIO CANDIDO

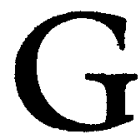

iuseppe Ungaretti regeu a cadeira de Língua e Literatura Italiana na Universidade de São Paulo de 1937 a 1942, mas a sua ação foi grande também fora de aula - em conversas, reuniōes, passeios. Quando voltou à Itália foi como se tivessem arrancado alguma coisa da cidade, que ele marcou profundamente em muitos setores, embora sem rumor. Salvo um ou dois casos, os seus maiores amigos e os que mais sofreram a sua influência não foram seus alunos regulares, no sentido escolar; mas todos foram seus discípulos e continuam fiéis à sua lembrança. Há mesmo uma espécie de maçonaria entre eles, alimentada por alusóes a experiências comuns, evocaçóes de fatos pitorescos ou comoventes que nós presenciamos e cujo relato nos chega, ás vezes, de torna-viagem depois de um percurso mais ou menos longo que os lançou, como um ciclo de Ungaretti, na mitologia artística e intelectual da cidade.

Pertencem a esse ciclo o conselho drástico dado a um jovem pintor, que insistia pela sua opiniáo, e a quem sugeriu, vendo os seus quadros leves e azuis, que matasse o pai e fosse fare $l$ ' amore antes de pintar. $\mathrm{Ou}$ as expressóes abafadas diante de um quadro de Picasso na casa de Oswald de Andrade: io non so come si fa per arripare a questa purezza!

Ou um alegre quiproquó, lá mesmo, por causa de uma gaffe do anfitriáo, que dizia ao poeta admirar muito um dos seus poemas, quando na verdade tratava-se de paródia. É ainda o caso do juízo arrasante sobre Bernanos, que vivia aqui e era endeusado pelos admiradores, a um dos quais ele bradou como resumo de apreciaçáo: C' est un furceur! Ou a conclusão inesperada sobre o Cardeal Mercier, depois de explicar longamente a sua tremenda erudiçáo: $E$ n somme, un sombre crétin! $\mathrm{Ou}$, durante a visita a um leprosário, o entusiasmo por uma mulher de Sorocaba que, sem se contaminar, já tinha vivido sucessivamente com sete doentes, que preferia porque tiravam mais esmola. Ne fare una novella cruda, boccactiesca - exclamava entusiasmado Ungaretti, com a sua gargalhada aguda e convulsiva. Famosa ficou a sua definiçăo dos requisitos hormonais generosos do literato, em comparaçăo com a insignificância dos que atribuía ao sociólogo.

Tudo isso mantém aqui a sua presença viva e afetuosa, um culto familiar que bem revela a ação desse grande poeta que nos ensinou tanta 
coisa e é dos poucos estrangeiros de alto porte que amam e sentem o Brasil em profundidade. Quem não lembra a sua mágoa em sair daqui sem ter visto as obras do Aleijadinho - ele que revelou a muitos a importância e o significado do barroco literário, evocado desde o papagaio auriverde do rei Dom Dinis como constante portuguesa (1). As traduçóes de Mário de Andrade, que publicou na revista $L$ ' Approdo e leu em São Paulo por ocasião de uma estada rápida em 1954, revelam penetraçáo poucas vezes alcançada na intimidade de nossa poesia. No seu poema Semantica (de Un grido e paesaggi) serpeia um filáo amazônico e, como diria Oswald de Andrade, antropofágico, revelando a identificaçăo compreensiva. Todos nós somos gratos a Ungaretti por essa atençáo seletiva e concentrada a respeito do Brasil, que permite manter o melhor diálogo por sobre o mar.

De outro lado, é notória a ligaçăo quase mística com a nossa terra, onde está sepultado o seu filho Antonio - Antonietto -, cuja morte dá vida a tantos versos de Dolore.

Ele nos trouxe muito da cultura européia, ele que é italiano do Egito de formaçăo francesa, através da maneira densa e dramática com que não apenas cria e interpreta, mas transmite. E a experiência da sua poesia calorosa e descarnada foi um impacto tornado mais forte pela sua presença. Daí termos procurado vivê-la com intensidade. Daí mais de um entre nós ter copiado integralmente os textos de Allegria e sentimento del tempo, para sentir nessa espécie de rito simpático, os pontos de ossificaçáo da sua poesia misteriosa e humana. E quando a máquina de escrever lançava no espaço branco os versos parcimoniosos e sibilinos, era como se o trabalho do nosso grande amigo ficasse mais inteligivel, com as palavras renascendo sob os dedos atentos que, na sua inexperiência, procuravam decifrá-las.

Não foi menos decisivo o que ensinou como atitude de leitura,

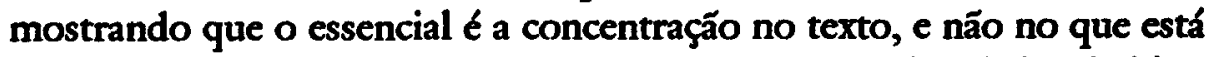
antes ou depois. E era assim que construía as suas aulas cheias de idas, vindas e descobertas. Elas faziam entender melhor que o seu próprio produto poético, depurado até dificultar o fôlego da compreensão, tinha como substrato uma erudiçáo caudalosa, e decorria do ataque dos problemas por todos os lados, para poder sondar verticalmente as profundidades. Sentíamos entáo que o poema despojado e essencial tinha as experiências mais fortes como lastro e era realmente $\mathrm{o}$ afloramento mais puro da poesia.

Nas aulas Ungaretti revelou o que significa o diálogo do pensamento e da sensibilidade com o texto. Mostrou como, ao toque do leitor capaz, surgem mundos que parecem brotar das entrelinhas, minar do 
vão das letras, deslizar das maiúsculas para as minúsculas como se umi fermentação incessante e contida esperasse o leitor escolhido. Quanta: vezes, em aulas sucessivas, voltava atrás para corrigir a leitura precedentı de algum trecho ou poema. E assim duas, três vezes, cada uma das quai apagava a anterior e se oferecia como a mais límpida, a mais insuperável para no entanto, na aula seguinte, ceder por sua vez o lugar a outra aindi mais lídima e completa.

Nas aulas havia uma fase tranqüila de aproximaçáo metódica; ha via depois uma fase de arroubo, onde a imaginaçáo o atirava sobre c

Giussepe Ungaretti

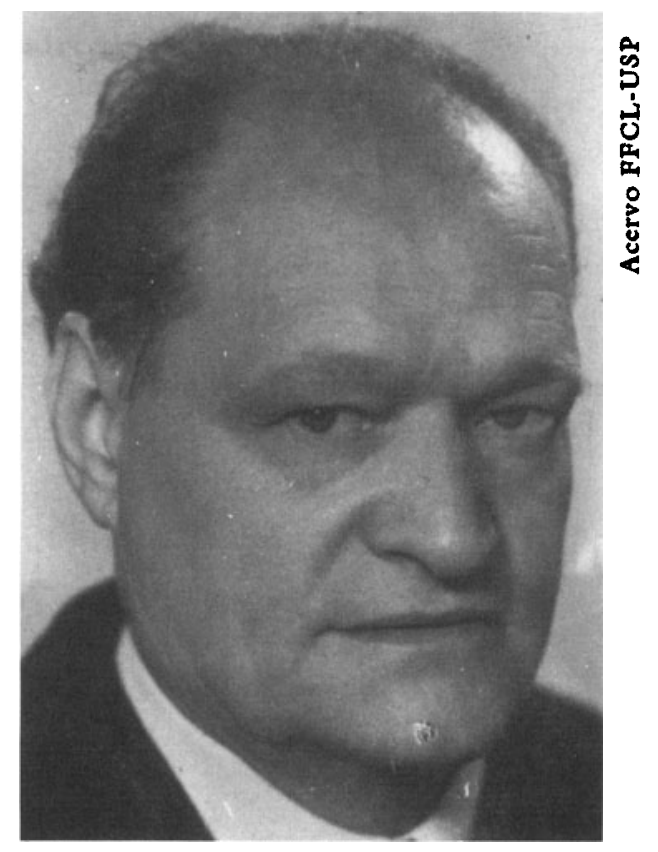

quadro negro de giz em riste, com as costas voltadas para os ouvintes perseguindo em altos brado o curso fugidio da intuiçáo; $e$ havia as fase de volta ao momento, com a voz de novo calma, quando as conclusóe emergiam do tumulto e se ordenavam na mais nítida coerência; havi: ainda os momentos de luta com a pasta de livros de couro preto, dua alças compridas e uma curiosa vareta de metal que servia para prendê-la e que o poeta manipulava em todos os sentidos, fazendo e refazendo ، arranjo, para logo abandoná-lo e, em novo rompante, voltar ao combat contra a noite impassível da lousa.

Teria ele consciência dessas manobras (pensávamos), ou estari com a mente fora de tudo, de nós, da sala, da pasta - deslizando par 
o mundo da poesia através de espiral inquieta que o giz traçava no ar? Leopardi e o senso do fragmentário; a atuaçăo do Cristianismo na literatura; as glórias do Renascimento; o sonho austero e humano de Manzoni - tomavam corpo nessas sessōes de invocaçäo crítica, mostrando mais uma vez os fortes alicerces do mundo de emoçáo e idéia pressuposto na página branca, riscada brevemente pelas palavras, que a nossa máquina copiava. E do professor, do poeta, do amigo, compunha-se a cada instante o traçado completo e perfeito do homem exemplar.

\author{
Quando tropo \\ in questo mio silenzio \\ una parola \\ scapata d nella mia vita \\ come un abisso.
}

\title{
Nota
}

1 Ungaretri só póde visitar as cidades históricas de Minas em 1966, na companhia de Sergio Frederico (Nota de 1992).

Antonio Candido é professor emérito da Faculdade de Filosofia, Letras e Ciências Humanas da USP.

Texto extraldo de Brigada ligeira c outros escritos (Editora da Unesp, 1992, p.219-222). 